\title{
Meta-analysis of gene expression changes in response to radiation exposure
}

\author{
John Kirtley ${ }^{1}$, Eric C Rouchka ${ }^{1 *}$, Robert M Flight ${ }^{2}$, Palaniappan Sethu ${ }^{3}$, John W Eaton ${ }^{4}$, Robert S Keynton ${ }^{3}$, \\ The University of Louisville Research Group for Diagnosing and Mitigating Human Exposure to Radiation Using \\ Micro-Nanotechnology
}

From 10 ${ }^{\text {th }}$ Annual UT-ORNL-KBRIN Bioinformatics Summit 2011

Memphis, TN, USA. 1-3 April 2011

\section{Background}

Given NASA's recent focus on long-duration space travel, potential adverse effects on astronauts of ionizing radiation need to be minimized. Levels of exposure for astronauts on such flights can be high enough to cause damage to DNA, possibly causing mutation and cancer. By analyzing the mRNA expression levels of genes exposed to different doses of gamma radiation in laboratory experiments, it can be determined which genes act as biomarkers of dosage-specific radiation exposure which can then be used on lab-on-a-chip (LOC) diagnostic platforms for early detection of ionizing radiation exposure.

\section{Methods}

Currently, our group is incorporating three genes known to be involved in double-stranded DNA damage and repair, including: $\mathrm{p} 21, \mathrm{p} 53$, and $\gamma \mathrm{H} 2 \mathrm{AX}$. While these genes should show up in response to ionizing radiation exposure, they are not ideal biomarkers due to their lack of specificity. Therefore, by using meta-analysis, our goal is to gain further insight into additional biomarkers for radiation exposure. More than 40 publicly-available data sets appropriate to our study were obtained from the online repository, Gene Expression Omnibus (GEO) [1]. These gene expression experiments were subsequently categorized by radiation type and dose. Metaanalysis was performed using a combination of statistical tests using the Differential Expression via Distance Synthesis (DEDS) package [2].

\footnotetext{
* Correspondence: eric.rouchka@louisville.edu

'Department of Computer Engineering and Computer Science, University of Louisville, Louisville, KY, 40292, USA

Full list of author information is available at the end of the article
}

\section{Results}

Preliminary meta-analysis of these publicly available datasets yields potential biomarkers from the P53 signaling pathway (CDKN1A, GADD45A, MDM2, PMAIP1), stress response transcription factors (ATF3, JUN, JUNB, JUND), and cell surface receptors (CD69, CD70, CD83). Additional microarray experiments involving irradiated blood samples are underway. The analysis of both publicly available data and our own datasets will yield a broader picture of genes most sensitive to exposure of ionizing radiation for use as biomarkers on LOC diagnostic platforms for early detection of radiation exposure, leading to subsequent treatment.

\section{Acknowledgments \\ Members of the University of Louisville Research Group for Diagnosing and Mitigating Human Exposure to Radiation Using Micro-Nanotechnology include Robert W. Cohn, John Eaton, William D. Ehringer, Andre M. Gobin, Andrea S. Gobin, Balaji Panchapakesan, Eric C. Rouchka, Palaniappan Sethu, and Robert S. Keynton. This work was supported by the National Aeronautics and Space Administration (NNX10AJ36G) and the National Institutes of Health (NIH) (P2ORR016481, P30ES014443). Its content is solely the responsibility of the authors and does not necessarily represent the official views of NASA, NCRR, NIEHS, or NIH.}

\section{Author details}

'Department of Computer Engineering and Computer Science, University of Louisville, Louisville, KY, 40292, USA. ${ }^{2}$ Department of Anatomical Sciences and Neurobiology, University of Louisville, Louisville, KY, 40292, USA.

${ }^{3}$ Department of Bioengineering, University of Louisville, Louisville, KY, 40292, USA. ${ }^{4}$ Department of Medicine, University of Louisville, Louisville, KY, 40292, USA.

Published: 5 August 2011

\section{References}

1. Barrett TD, Wilhite SE, Ledoux P, Rudnev D, Evangelista C, Kim IF, Soboleva A, Tomashevsky M, Marshall KA, Phillippy KH, Sherman PM, Muertter RN, Edgar R: NCBI GEO: archive for high-throughput functional genomic data. Nucleic Acids Res 2009, 37:D5-15.

\section{Ciomed Central}

(c) 2011 Kirtley et al; licensee BioMed Central Ltd. This is an open access article distributed under the terms of the Creative Commons Attribution License (http://creativecommons.org/licenses/by/2.0), which permits unrestricted use, distribution, and reproduction in any medium, provided the original work is properly cited. 
2. Yang YH, Xiao Y, Segal MR: Selecting differentially expressed genes from microarray experiment by sets of statistics. Bioinformatics 2005 , 21:1084-1093.

doi:10.1186/1471-2105-12-S7-A20

Cite this article as: Kirtley et al:: Meta-analysis of gene expression changes in response to radiation exposure. BMC Bioinformatics 201112 (Suppl 7):A20.

Submit your next manuscript to BioMed Central and take full advantage of:

- Convenient online submission

- Thorough peer review

- No space constraints or color figure charges

- Immediate publication on acceptance

- Inclusion in PubMed, CAS, Scopus and Google Scholar

- Research which is freely available for redistribution 